\title{
Broadening the clinical spectrum of ALGS: an Egyptian cohort with five novel mutations in JAG1 gene
}

Rabab Khairat ${ }^{{ }^{*}}$ (D), Hanaa El-Karaksy², Hala T. El-Bassyouni ${ }^{3}$, Ahmed K. Saad ${ }^{1}$, Eman Rabie ${ }^{1}$, Khaled Hamed ${ }^{3}$ and Noha A. Yassin²

\begin{abstract}
Background: Alagille syndrome (ALGS) is a rare autosomal dominant multisystem disorder that affects the liver, heart, eyes, vertebrae, and kidneys and is associated with characteristic facies. This work aimed to study the spectrum of the clinical features of ALGS in an Egyptian cohort of patients in conjunction with partial sequencing of the JAG1 gene.

Methods: This study included 17 pediatric ALGS patients diagnosed on clinical grounds: facial features, cholestatic liver disease, and cardiac, vertebral, and ocular findings. Molecular analysis was conducted in 10 selected exons of the JAG1 gene.

Results: The clinical features of ALGS included cholestatic liver disease (100\%), facial dysmorphism (100\%), cardiac abnormalities (88.2\%), butterfly vertebrae (64.7\%), posterior embryotoxon (35.2\%), poor growth (41\%), xanthomata (11.8\%), and hiatus hernia (11.8\%). Five novel pathogenic JAG1 mutations were identified in this study, including two nonsense mutations, one splicing mutation, one frameshift insertion, and one frameshift deletion. In two patients, the mutations were confirmed to be de novo, as the mutations could not be detected in both parents.
\end{abstract}

Conclusion: Five novel JAG1 pathogenic variants were identified in this study. This is the first molecular study to report pathogenic mutations in the JAG1 gene within an Egyptian cohort of children with ALGS.

Keywords: Alagille syndrome, ALGS, Butterfly vertebrae, Cholestasis, Congenital heart disease, Characteristic facies, JAG1 gene, Optic nerve drusen, Paucity of intrahepatic bile ducts, Posterior embryotoxon

\section{Introduction}

Alagille syndrome (ALGS; OMIM 118450) is a rare pediatric autosomal dominant multisystem disorder with characteristic facial features and abnormalities in the liver, heart, eyes, skeleton, and kidneys. The onset becomes evident in infancy or early adolescence [1], 2, $20,27,28$. ALGS prevalence is $\sim 1: 70,000$ live births and is caused mainly by mutations in the JAG1 or NOTCH2

\footnotetext{
*Correspondence: rk.abd-elhay@nrc.sci.eg; rababncr2001@hotmail.com ${ }^{1}$ Department of Medical Molecular Genetics, Human Genetics and Genome Research Institute, National Research Centre, Cairo, Egypt Full list of author information is available at the end of the article
}

gene: 94\% of ALGS patients are associated with a mutation in the $J A G 1$ gene, whereas $1 \%$ to $2 \%$ of patients are due to the NOTCH2 gene [22, 24]. ALGS may differ greatly in symptoms and severity between individuals. Common clinical presentations include a paucity of intrahepatic bile ducts leading to jaundice and pruritus, congenital heart defects, butterfly vertebrae, posterior embryotoxon, growth retardation, and distinct facial characteristics [5] 8, 28. Renal, pancreatic, and vascular system diseases, notably intracranial vascular anomalies, are all known manifestations of ALGS, all of which contribute to the injuries and deaths they cause [19]. 
ALGS was the first identified condition implicating the Notch signaling pathway and the first human condition to be caused by the defective Notch ligand JAG1 gene [2] $7,28,31$. De novo pathogenic variants are identified in 50 to $70 \%$ of ALGS cases. The risk of siblings of a proband with an apparent de novo pathogenic variant is very low but still greater than the general population because of the possibility of germline mosaicism [21]. Reduced penetrance and variable expression are frequent, and somatic/germline mosaicism is also fairly common in this condition [31]. Roughly two thirds of detectable pathogenic variants in the JAG1 gene can be found in 10 out of 26 JAG1 exons, many of which have a functional effect on the JAG1 protein [33]. According to the reported exonic variants in Ensembl GRCh38.p13, the number of total exonic variants is 2305 , and $49 \%$ of the reported variants can be detected in a number of exons [12] [Gene: JAG1 (ENSG00000101384) - Variant Table - Homo sapiens - Ensembl Genome Browser 104, 11]. To date, Egyptian ALGS patients were not subject to any molecular studies just a few clinical records of the disease and its clinical features [13-15]. The molecular diagnosis and detection of a JAG1 gene mutation permit effective genetic counseling and prenatal diagnosis. The principal objective of this study was to shed light on the clinical presentation of ALGS patients in an Egyptian cohort in conjunction with screening on a number of selected exons in JAG1 gene by Sanger sequencing.

\section{Patients and methods}

This cohort included 17 ALGS patients from 16 unrelated families; 2 patients were twin brothers. They were recruited from the Pediatric Hepatology Unit, Cairo University Pediatric Hospital (Cairo, Egypt) and the Clinical Genetics Clinic, National Research Centre. The ALGS diagnosis was based on the presence of three or more of the five major clinical features: chronic cholestasis, cardiovascular abnormalities, skeletal anomalies, posterior embryotoxon seen on slit-lamp examining the anterior chamber or optic nerve drusen detected by ocular ultrasound, and characteristic facies, including triangular face, prominent forehead, hypertelorism with deep-set eyes, and pointed chin [17].

The following data were collected:

o Clinical data, including growth parameters, jaundice, hepatomegaly, splenomegaly, pruritus/scratch marks, characteristic facies, xanthomas, cardiac murmurs, and evidence of renal disease

p Liver function tests for evidence of cholestatic liver disease: total and direct serum bilirubin, alanine aminotransferase (ALT), aspartate aminotransferase (AST), alkaline phosphatase (ALP), $\gamma$-glutamyl trans- peptidase (GGT), serum albumin, prothrombin time, concentration, and international normalized ratio (INR)

q Lipid profile: total cholesterol, low-density lipoprotein-cholesterol (LDL-C), high-density lipoproteincholesterol (HDL-C), and triglycerides

r X-ray cervical, thoracic, and lumbar vertebrae

s Echocardiography

$\mathrm{t}$ Ocular examination, including slit-lamp examination for posterior embryotoxon and ocular ultrasound for optic nerve drusen

u Histopathological examination of liver biopsy when available. A paucity of bile ducts was defined as a ratio of interlobular bile ducts to portal areas of $<0.5$ to 0.7. A sample containing at least six portal tracts was considered adequate [19].

\section{DNA extraction}

About 3-5 mL whole blood were collected for genomic DNA extraction using either the salting-out protocol [26] or the QIAamp DNA Mini Kit (Qiagen; according to manufacturer's recommendations). The isolated DNA concentration was determined roughly using the NanoDrop spectrophotometer 2000 (NanoDrop Technologies, Montchanin, DE, USA) at 260/280 nm.

\section{Primer design and exon amplification of the JAG1 gene}

Specific primers of a number of selected JAG1 exons have been designed using Primer 3 and the available genomic reference sequence in National Center for Biotechnology Information (NCBI) (NM_000214.3). According to Warthen et al. [33], 10 exons were selected, including exons $2,4,6,7,9,16,17,18,23$, and 24, according to the reported exonic variants on Ensemble GRCh38 assembly. Collectively, 1119 of the total 2305 mutations were detected in the selected exons [12] [Gene: JAG1 (ENSG00000101384) - Variant Table - Homo sapiens - Ensembl Genome Browser 104, 11]. The primers have been designed to flank the coding regions. The extracted DNA has been used for the polymerase chain reaction (PCR) amplification of different exons.

\section{Sanger sequencing and segregation studies}

The purified PCR products were utilized for the Sanger sequencing method using BigDye ${ }^{\mathrm{TM}}$ Terminator version 3.1 Cycle Sequencing Kit (Applied Biosystems, Thermo Fischer Scientific) as recommended by the manufacturer. The sequencing results were analyzed using Bioedit, and the resulted sequences were aligned to the nucleotide database using BLAST, NCBI. The detected variants 
were examined in other members of the patients' families to deliver proper genetic counseling to the patients' families.

\section{Evaluation and prediction of the mutation effect}

The effect of the mutation on the gene function was assessed by checking the dbSNP and Clinvar databases and using a number of different programs and algorithms, including Polyphen2 and Mutation tester. The Varsome platform was used to classify the variant based on the American College of Medical Genetics and Genomics (ACMG) and the Association of Molecular Pathology guidelines.

\section{Results}

The study included 17 patients diagnosed clinically with ALGS; 9 (52.9\%) patients were males. Seven (41.2\%) patients had growth failure. All patients presented with cholestatic jaundice before age 3 months. On recruitment, 9 of 17 patients still had cholestatic jaundice. The characteristic facies were present in all $(100 \%)$ patients. One patient presented with thalassemia intermedia in addition to ALGS, but he had no characteristic facies of thalassemia (Fig. 1A). Hepatomegaly was found in $11(64.7 \%)$ patients, and splenomegaly was found in 4 $(23.5 \%)$ patients. None had ascites. Xanthomata were detected in $2(11.8 \%)$ patients. Liver biopsy was done in 12 patients; a paucity of interlobular bile ducts was present in $5(41.7 \%)$ patients. Fifteen $(88.2 \%)$ patients had abnormal findings in echocardiography. Peripheral pulmonary stenosis was the most common (11 patients): bilateral in 6 patients and unilateral in 5 patients. Patent ductus arteriosus was present in 5 patients, an atrial septal defect was present in 2 patients, and a ventricular septal defect was present in 1 patient. Butterfly vertebrae were present in 11 (64.7\%) patients (Fig. 1B). Posterior embryotoxon was found in $6(35.3 \%)$ patients. Optic nerve drusen were found in 1 (5.9\%) patient. Renal abnormalities were found in only 1 patient (5.9\%) in the form of pelvi-ureteric junction obstruction. Upper endoscopy was performed for 2 patients who complained of hematemesis; hiatus hernia was diagnosed in both patients, and one of these patients had grade 1 esophageal varices (Table 1). Liver function tests and lipid profiles are shown in Table 2.

\section{Molecular and segregation analysis}

Among the 17 studied cases, five mutations have been detected. All identified mutations in five patients were novel. All five detected variants were replicated using the patients' DNA and available family members' DNA. Segregation study in two patients confirmed that the detected mutations were de novo (Patients 2 and 4), as the mutations could not be detected in both parents. The mutation in Patient 5 [JAG1: c.2280_2281delGG p. (V761Qfs*24)] was detected in his mother; therefore, it was considered a familial mutation. In contrast, in the other two patients, the DNA of only one parent (whether mother or father) was available and was normal. Pedigree of the patients' families was summarized in Fig. 2. Table 3 shows the detailed results of the DNA sequencing of the JAG1 gene (NM_000214.3).

All mutations were considered pathogenic according to the standards of the ACMG classification. They are null variants (e.g., nonsense, frameshift, and canonical \pm 1 or 2 splice sites) in a gene where loss-of-function is a known disease mechanism and fulfilled the PVS1 rule of the ACGM guidelines. The detected mutations included two nonsense mutations, one splicing mutation, one frameshift insertion, and one frameshift deletion (Table 3; Fig. 2).

All five children with JAG1 mutations had cardiovascular involvement. Peripheral pulmonary stenosis (4 of 5) was the most frequent cardiac anomaly. Hiatus hernia was observed by upper endoscopy in 2 children and pelvi-ureteric obstruction in 1 child. One child had thalassemia intermedia (Table 3).

\section{Discussion}

ALGS is a multisystem disorder with variable phenotypic penetrance even in the same family [32]. Seven patients (41\%) presented with poor growth. Growth failure may occur for several causes in ALGS. Reduced bile flow often results in the malabsorption of vital nutrients that affects the growth of these children [29]. The extreme height limits seen in many patients may also be a feature of the vertebral and skeletal abnormalities seen in ALGS [18]. Some ALGS patients have been reported to have hypothyroidism. Growth hormone insensitivity has also been reported [4]. Pancreatic insufficiency tends to affect a considerable number of patients, up to $42 \%$ [10].

All patients in our study presented with facial dysmorphism and hepatic manifestations, as has previously been noted in both Vietnamese and European/American ALGS cohorts (Table 1) [23, 33]. However, at recruitment time, cholestatic jaundice; was detected in $52.9 \%$. The absence of jaundice does not preclude cholestasis evident by the severe pruritus that almost all patients suffered from. A paucity of interlobular bile ducts was detected in $29.4 \%$. Biopsy performed in early infancy may not show bile duct paucity in ALGS patients [31]. The median [interquartile range (IQR)] age at biopsy of five patients whose biopsy showed a paucity of interlobular bile ducts was 3 (2.5) months. The median (IQR) age at biopsy of the other seven patients whose biopsy showed neonatal hepatitis was 2 (2.5) months. Comparing the 


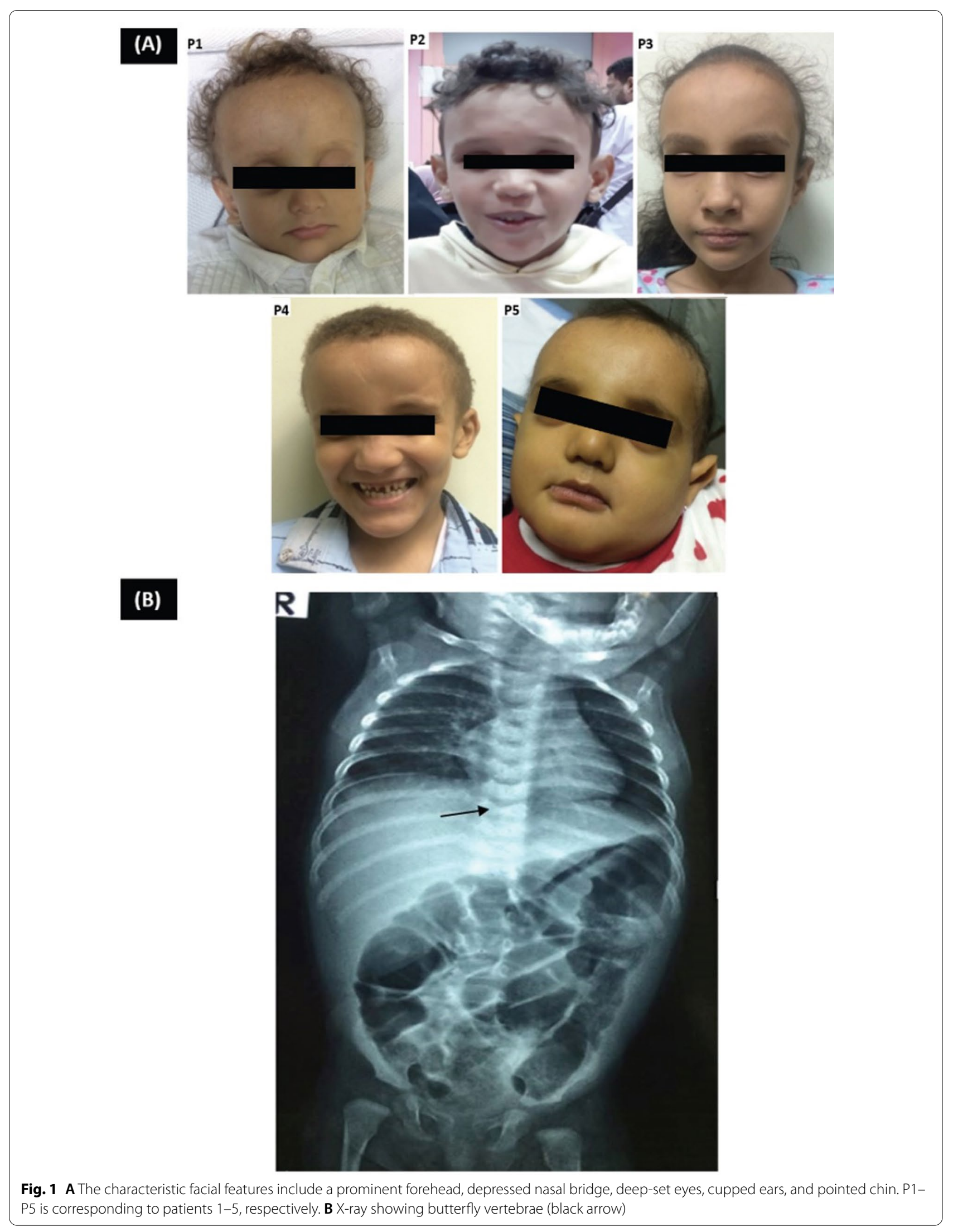


Table 1 Characteristics of ALGS patients in our cohort in comparison to previously reported studies

\begin{tabular}{|c|c|c|c|}
\hline Characteristics & $\begin{array}{l}\text { The present study No. } \\
\text { patients }(n=17)\end{array}$ & $\begin{array}{l}\text { Vietnamese ALGS individuals } \\
\text { No. patients }(n=18)[23]\end{array}$ & $\begin{array}{l}\text { European/American ALGS } \\
\text { individuals No. patients } \\
(n=326)[33]\end{array}$ \\
\hline Facial dysmorphism & $100 \%$ & Not detected & $96 \%$ \\
\hline Hepatic manifestation & $100 \%$ & $100 \%$ & $97.3 \%$ \\
\hline Jaundice & $52.9 \%$ & & \\
\hline Pruritus & $88.2 \%$ & & \\
\hline Hepatomegaly & $64.7 \%$ & & \\
\hline Elevated liver enzymes & $94.1 \%$ & & \\
\hline Paucity of interlobular bile ducts by liver biopsy & $29.4 \%$ & & \\
\hline Splenomegaly & $23.5 \%$ & Not detected & Not detected \\
\hline Cardiac abnormalities & $88.2 \%$ & $94 \%$ & $97.9 \%$ \\
\hline Peripheral pulmonary stenosis & $73.4 \%$ & & \\
\hline Patent ductus arteriosus & $33.4 \%$ & & \\
\hline Atrial septal defect & $13.4 \%$ & & \\
\hline Ventricular septal defect & $6.7 \%$ & & \\
\hline Skeletal abnormalities (Butterfly vertebrae) & $64.7 \%$ & $94.1 \%$ & $57.9 \%$ \\
\hline Eye examination & $41.1 \%$ & $100 \%$ & $68.3 \%$ \\
\hline Posterior embryotoxon & $35.2 \%$ & & \\
\hline Optic nerve drusen & $5.9 \%$ & & \\
\hline Xanthoma & $11.8 \%$ & Not detected & Not detected \\
\hline Hiatus hernia by upper endoscopy & $11.8 \%$ & Not detected & Not detected \\
\hline Pelvi-ureteric obstruction & $5.9 \%$ & $27.3 \%$ & $30.5 \%$ \\
\hline
\end{tabular}

Table 2 Liver function tests and lipid profile of the studied children

\begin{tabular}{ll}
\hline & Value \\
\hline Total bilirubin (mg/dL), median (range) & $2.7(0.1-10.4)$ \\
Direct bilirubin (mg/dL), median (range) & $1.5(0-9.7)$ \\
ALT (IU/L), median (range) & $171(42-642)$ \\
AST (IU/L), median (range) & $182(43-430)$ \\
GGT (IU/L), median (range) & $391(2-956)$ \\
ALP (IU/L), mean \pm SD & $599 \pm 250.4$ \\
Albumin (g/dL), mean $\pm S D$ & $3.5 \pm 0.4$ \\
INR, mean $\pm S D$ & $1 \pm 0$ \\
Total cholesterol, mean $\pm S D$ & $244 \pm 44.9$ \\
Triglyceride, mean $\pm S D$ & $190 \pm 60$ \\
HDL-C, mean $\pm S D$ & $59.9 \pm 9.4$ \\
LDL-C, mean $\pm S D$ & $194 \pm 65$
\end{tabular}

$\mathrm{ALP}=$ alkaline phosphatase; $\mathrm{ALT}=$ alanine aminotransferase; $\mathrm{AST}=$ aspartate aminotransferase; $\mathrm{GGT}=$ gamma glutamyl transpeptidase; $\mathrm{HDL}=$ high density lipoprotein; INR = international normalized ratio; $L D L=$ low density lipoprotein

clinical picture of the Vietnamese and European/American ALGS patients with our cohort, the cardiac, skeletal, eye and renal abnormalities were less in our study $88.2 \%$, $64.7 \%, 41.1 \%$ and $5.9 \%$ respectively [23, 33] (Table 1 ).

Xanthomas were noticed in $2(11.8 \%)$ patients who had hypercholesterolemia, less than double the upper limit of normal. Hannoush et al. [16] described an infant with ALGS who had a previously undescribed frameshift pathogenic mutation in the JAG1 gene and presented with xanthomatosis and had hypercholesterolemia more than twice the upper limit of normal. Fifteen (88.2\%) patients had abnormal findings in echocardiography (peripheral pulmonary stenosis in 11 patients). Ninety percent of ALGS patients had congenital heart disease [30]. Peripheral pulmonary stenosis is the most common $[6,9]$. Butterfly vertebrae were detected in $64.7 \%$ of the patients; this finding was described previously in $94.1 \%$ [23], 57\% [9]33, and 47\% [6]. Posterior embryotoxon was present in $35.2 \%$, much lower than the previously published cohort (68\%; [14] and in another published cohort 79\% [9]. Hiatus hernia was an interesting observation detected by upper endoscopy in $2(11.8 \%)$ patients. In addition, one of our ALGS patients presented with thalassemia intermedia in addition to ALGS.

Most Egyptian records discussed and investigated the clinical findings of ALGS, but no molecular studies were reported. In this study, a group of 17 patients with typical clinical manifestations of ALGS have been examined and screened for mutations in 10 of JAG1 exons where $49 \%$ of JAG1 mutations were reported according to the updated Ensembl database $[12,33]$ [Gene: JAG1 (ENSG00000101384) - ( $\underline{\text { Variant }}$ 


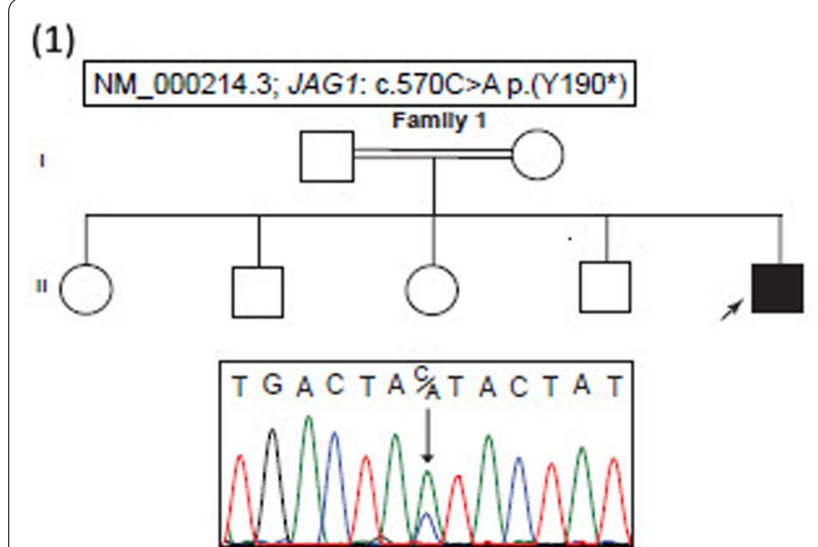

(2)

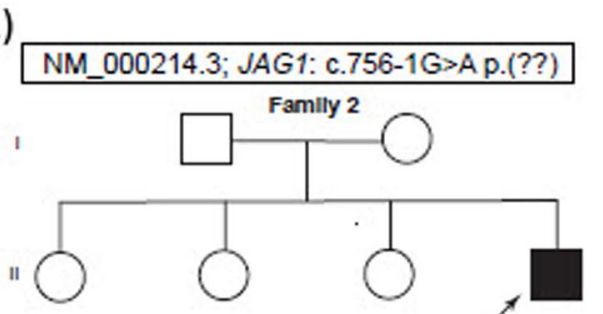

(3)

NM_000214.3; JAG1: c.928G>A p.(G310*)

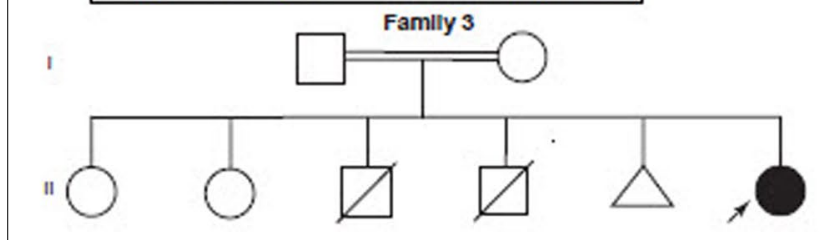

(4)
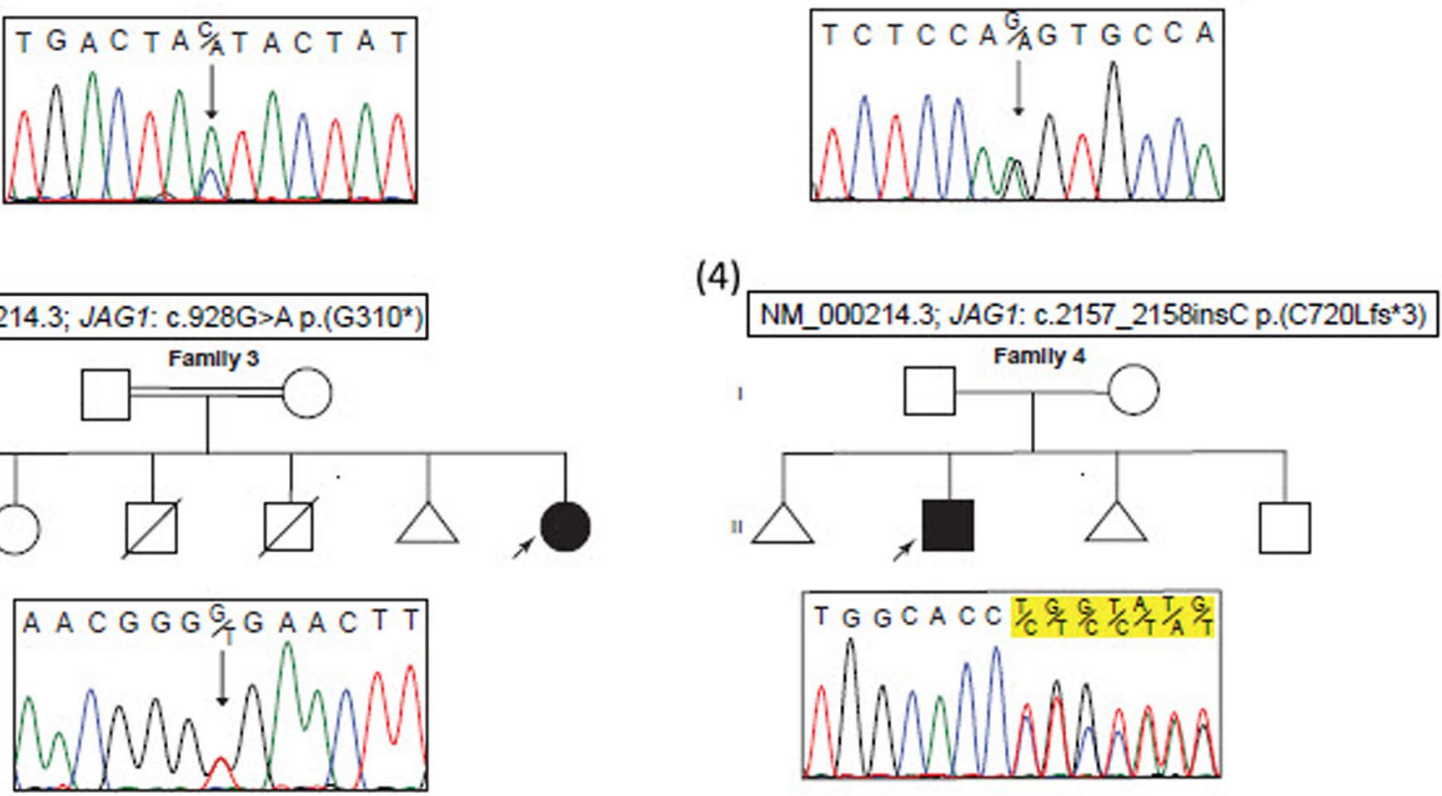

(5)

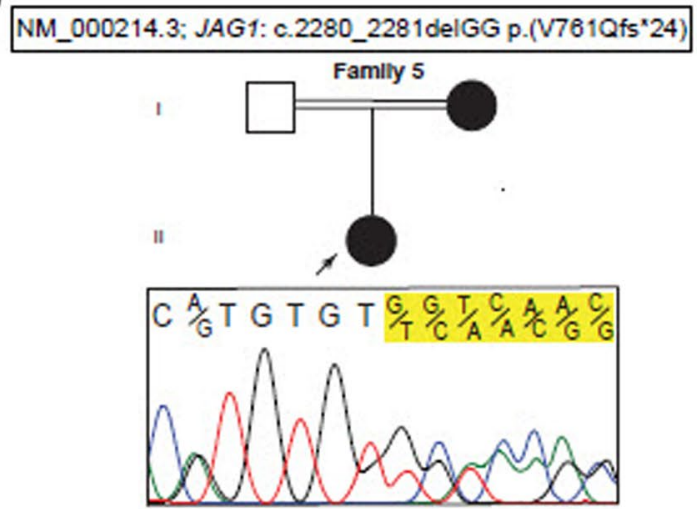

Fig. 2 Patients'families' pedigree and chromatograms of DNA sequencing results showing detected heterozygous mutations in different families $(1-5)$. The black arrow points to the detected variants in families 1 to 3 . The highlighted sequences in sequencing chromatograms show the frameshift in the DNA sequence due to the detected variants in families 4 and 5

Table-Homo sapiens-Ensembl Genome Browser $104,11)]$ with a high incidence of pathogenic variants. Screening in the selected 10 exons is first step to study the rest of patients extensively with high throughput technology like whole exome sequencing. Especially, there is a probability of other genetic causes like mutations in NOTCH2 gene or CNVs in JAG1 gene [12, 22, 24].

Five patients have been confirmed by PCR and Sanger sequencing to have novel pathogenic heterozygous mutations in the JAG1 gene. These mutations are inherited in an autosomal dominant pattern; however, they are de 
Table 3 Detailed results of the DNA sequencing of the JAG1 gene

\begin{tabular}{|c|c|c|c|c|c|c|c|c|}
\hline Patient no & HGVS coding & HGVS protein & Exon & Domain & $\begin{array}{l}\text { Coding } \\
\text { impact }\end{array}$ & $\begin{array}{l}\text { ACGM } \\
\text { classification }\end{array}$ & Reference & $\begin{array}{l}\text { Associated } \\
\text { clinical } \\
\text { features }\end{array}$ \\
\hline P1 & C. $570 C>A$ & p.Y190* & 4 & DSL & Nonsense & Pathogenic & Novel & $\begin{array}{l}\text { Bilateral periph- } \\
\text { eral pulmonary } \\
\text { artery stenosis } \\
\text { Patent ductus } \\
\text { arteriosus } \\
\text { Hiatus hernia }\end{array}$ \\
\hline P2 & c.756-1G > A & Intronic & Intron of ex.6 & Noncoding & Splicing & Pathogenic & $\begin{array}{l}\text { Novel and de } \\
\text { novo }\end{array}$ & $\begin{array}{l}\text { Bilateral periph- } \\
\text { eral pulmonary } \\
\text { artery stenosis }\end{array}$ \\
\hline P3 & $c .928 \mathrm{G}>\mathrm{T}$ & p.G310* & 7 & $\begin{array}{l}\text { EGF-like } \\
\text { repeats } 3\end{array}$ & Nonsense & Pathogenic & Novel & $\begin{array}{l}\text { Unilateral } \\
\text { peripheral pul- } \\
\text { monary artery } \\
\text { stenosis } \\
\text { Butterfly verte- } \\
\text { brae } \\
\text { Thalassemia } \\
\text { intermedia }\end{array}$ \\
\hline P4 & c.2157_2158insC & $\begin{array}{l}\text { p.(C720Lfs } \\
\text { Ter 3) }\end{array}$ & 17 & $\begin{array}{l}\text { EGF-like } \\
\text { repeats } 13\end{array}$ & $\begin{array}{l}\text { FS insertion } \\
\text { and termina- } \\
\text { tion after } 3 \\
\text { amino acids }\end{array}$ & Pathogenic & $\begin{array}{l}\text { Novel and de } \\
\text { novo }\end{array}$ & $\begin{array}{l}\text { Unilateral } \\
\text { peripheral pul- } \\
\text { monary artery } \\
\text { stenosis } \\
\text { Ventricular } \\
\text { septal defect } \\
\text { Butterfly verte- } \\
\text { brae } \\
\text { Pelvi-ureteric } \\
\text { junction } \\
\text { obstruction }\end{array}$ \\
\hline P5 & $\begin{array}{l}\text { c.2280_2281delGG } \\
\text { p. (V761Qfs*24) }\end{array}$ & $\begin{array}{l}\text { p. } \\
(\text { V761Qfs*24) }\end{array}$ & 18 & $\begin{array}{l}\text { EGF-like } \\
\text { repeats } 14\end{array}$ & $\begin{array}{l}\text { FS and } \\
\text { termination } \\
\text { of the protein } \\
\text { after } 25 \text { amino } \\
\text { acids }\end{array}$ & Pathogenic & Novel & $\begin{array}{l}\text { Patent foramen } \\
\text { ovale } \\
\text { Left ventricular } \\
\text { hypertrophy } \\
\text { Butterfly verte- } \\
\text { brae } \\
\text { Posterior } \\
\text { embryotoxon }\end{array}$ \\
\hline
\end{tabular}

ACMG = American College of Medical Genetics; DSL = Delta/Serrate/Lag-2 Domain, EGF=epidermal-growth-factor-like FS, frameshift; HGVS, Human Genome Variation Society; P, patient; Ter, termination

novo in half of the cases, as reported by other authors [29]. In this study, examination of both parents' DNA confirmed two mutations to be de novo (patient 2 and 4) and one was a familial mutation. The mother of patient 5 showed characteristic facial features, including a triangular face, prominent forehead, hypertelorism with deepset eyes, and pointed chin. In the two other patients, only one parent was studied, and they had no history of the disease in their families. The detected mutations in this study are mostly null: nonsense, splicing, or indels frameshifting mutations. According to the ACMG guidelines, they are pathogenic and strongly affect the JAG1 protein [25]. This coincided with previous reports [3, 24, 31 . All detected mutations are novel variants and were not found in GnomAD exomes, and different prediction software suggested the pathogenic effect of all mutations. They are mostly in the coding sequences located in a mutational hot-spot and the well-established functional domain of the JAG1 protein.

All detected mutations were in the extracellular domains of the JAG1 protein. A mutation has been detected in the delta/serrate/lag-2 (DSL) domain (p.Y190*). Yuan et al. [34] reported a phenotype-genotype correlation between the whole deletion of DSL in the JAG1 gene and the severity of liver affection in ALGS patients. In this study, the most common mutation in the JAG1 gene was reported in epidermal growth factor (EGF)-like repeats. Three mutations have been detected in EGF-like repeats 3,13, and 14 and one in the cysteinerich region (Table 3). This is consistent with previous reports, which revealed a high incidence of mutations in EGF-like repeats of the JAG1 gene [7].

The limitation of this study is that not all exons of the JAG1 gene were studied due to a limited budget; 
however, the studied exons were chosen as hot-spots according to previous studies. No phenotype-genotype correlation could be drawn from only five mutations. Despite this limitation, the yield of novel pathogenic mutations on studying 10 of 26 exons is considered high.

In conclusion, this cohort is the first molecular study in ALGS within the Egyptian population. Five novel JAG1 pathogenic variants have been identified. Further studies are planned to cover the rest of the gene exons in more patients, which may help establish a genotype-phenotype correlation, and discover more about the prevalence of noticed polymorphic sites in the population to define its role and the ancestor of the detected mutations.

\section{Abbreviations}

ALGS: Alagille syndrome; ALT: Alanine aminotransferase; AST: Aspartate aminotransferase; ALP: Alkaline phosphatase; GGT: $\gamma$-Glutamyl transpeptidase; INR: International normalized ratio; LDL-C: Low-density lipoprotein-cholesterol; HDL-C: High-density lipoprotein-cholesterol; NCBI: National Center for Biotechnology Information; PCR: Polymerase chain reaction; ACMG: American College of Medical Genetics and Genomics; IQR: Interquartile range; EGF: Epidermal growth factor; DSL: Delta/serrate/lag-2; FS: Frameshift; HGVS: Human Genome Variation Society; P: Patient; Ter: Termination.

\section{Acknowledgements}

Not applicable.

\section{Authors' contributions}

RK has designed the study, undertook and supervised the molecular work, and undertook the write-up and revision of the manuscript. HE-K has supervised the clinical evaluation of patients, collected data, and undertook the write-up and revision of the manuscript. HTE-B has supervised the clinical evaluation of patients, collected data, and contributed to the write-up and revision of the manuscript. AKS and ER undertook the molecular work and participated in the write-up of the manuscript. $\mathrm{KH}$ has contributed to the clinical evaluation and collected data. NAY has contributed to the clinical evaluation, collected data, contributed to the write-up and revision of the manuscript, and contributed to the statistical analysis of the clinical data. All authors agreed to be accountable for all aspects of the work in ensuring that questions related to the accuracy or integrity of any part of the work are appropriately investigated and resolved. All authors read and approved the final manuscript.

\section{Funding}

This study was funded by NRC internal Project No. AR111304.

\section{Availability of data and materials}

The datasets used and/or analyzed during the current study are available from the corresponding author on reasonable request.

\section{Declarations}

\section{Ethics approval and consent to participate}

The study was approved by the Ethical Committee at the National Research Centre (Cairo, Egypt). Informed consent was signed by the patients and/or their parents and all studied family members.

\section{Consent for publication}

A written informed consent for publication was signed by the patients and/or their parents and all studied family members.

\section{Competing interests}

The authors declare no conflict of interest.

\section{Author details}

${ }^{1}$ Department of Medical Molecular Genetics, Human Genetics and Genome Research Institute, National Research Centre, Cairo, Egypt. ${ }^{2}$ The Pediatric Hepatology Unit, Department of Pediatrics, Faculty of Medicine, Cairo University, Cairo, Egypt. ${ }^{3}$ Department of Clinical Genetics, Human Genetics and Genome Research Institute, National Research Centre, Cairo, Egypt.

Received: 11 October 2021 Accepted: 28 December 2021

Published online: 03 March 2022

\section{References}

1. Alagille D, Odièvre M, Gautier M, Dommergues JP (1975) Hepatic ductular hypoplasia associated with characteristic facies, vertebral malformations, retarded physical, mental, and sexual development, and cardiac murmur. J Pediatr 86:63-71

2. Alagille D, Estrada A, Hadchouel M, Gautier M, Odièvre M, Dommergues JP (1987) Syndromic paucity of interlobular bile ducts (Alagille syndrome or arteriohepatic dysplasia): review of 80 cases. J Pediatr 110:195-200

3. Brennan A, Kesavan A (2017) Novel heterozygous mutations in JAG1 and $\mathrm{NOTCH} 2$ genes in a neonatal patient with Alagille syndrome. Case Reports in Pediatrics, 1368189

4. Bucuvalas JC, Horn JA, Carlsson L, Balistreri WF, Chernausek SD (1993) Growth hormone insensitivity associated with elevated circulating growth hormone-binding protein in children with Alagille syndrome and short stature. J Clin Endocrinol Metab 76:1477-1482

5. Chen Y, Liu X, Chen S, Zhang J, Xu C (2019) Targeted sequencing and RNA assay reveal a noncanonical JAG1 splicing variant causing Alagille syndrome. Front Genet 10:1363

6. Cho JM, Oh SH, Kim HJ, Kim JS, Kim KM, Kim GH, Yu E, Lee BH, Yoo HW (2015) Clinical features, outcomes, and genetic analysis in Korean children with Alagille syndrome. Pediatr Int Off J Jpn Pediatr Soc 57:552-557

7. Crosnier C, Driancourt C, Raynaud N, Dhorne-Pollet S, Pollet N, Bernard O, Hadchouel M, Meunier-Rotival M (1999) Mutations in JAGGED1 gene are predominantly sporadic in Alagille syndrome. Gastroenterology 116:1141-1148

8. Crosnier C, Lykavieris P, Meunier-Rotival M, Hadchouel M (2000) Alagille syndrome. The widening spectrum of arteriohepatic dysplasia. Clin Liver Dis 4:765-778. https://doi.org/10.1016/s1089-3261(05)70140-9

9. Di Pinto D, Adragna M (2018) Renal manifestations in children with Alagille syndrome. Anomalías renales en niños con síndrome de Alagille. Arch Argent Pediatr 116:149-153

10. Emerick KM, Rand EB, Goldmuntz E, Krantz ID, Spinner NB, Piccoli DA (1999) Features of Alagille syndrome in 92 patients: frequency and relation to prognosis. Hepatology 29:822-829

11. Gene: JAG1 (ENSG00000101384) - Variant table - Homo_sapiens Ensembl Genome Browser 104 (2021, August). Ensemble. https://www. ensembl.org/Homo_sapiens/Gene/Variation_Gene/Table?db=core;g= ENSG00000101384;r=20:10637684-10673999

12. Gilbert MA, Bauer RC, Rajagopalan R, Grochowski CM, Chao G, McEldrew D, Nassur JA, Rand EB, Krock BL, Kamath BM, Krantz ID, Piccoli DA, Loomes KM, Spinner NB (2019) Alagille syndrome mutation update: comprehensive overview of JAG1 and NOTCH2 mutation frequencies and insight into missense variant classification. Hum Mutat 40(12):2197-2220. https://doi.org/10.1002/humu.23879

13. El-Karaksy H, Hamed D, Fouad H, Mogahed E, Helmy H, Hasanain F (2017) Ocular findings in patients with cholestatic disorders of infancy: a single-centre experience. Arab J Gastroenterol Off Publ Pan-Arab Assoc Gastroenterol 18:108-113

14. El-Koofy NM, El-Mahdy R, Fahmy ME, El-Hennawy A, Farag MY, El-Karaksy HM (2011) Alagille syndrome: clinical and ocular pathognomonic features. Eur J Ophthalmol 21:199-206

15. Fattouh AM, Mogahed EA, Abdel Hamid N, Sobhy R, Saber N, El-Karaksy $H$ (2016) The prevalence of congenital heart defects in infants with cholestatic disorders of infancy: a single-centre study. Arch Dis Child 101:803-807

16. Hannoush ZC, Puerta H, Bauer MS, Goldberg RB (2017) New JAG1 mutation causing Alagille syndrome presenting with severe hypercholesterolemia: case report with emphasis on genetics and lipid abnormalities. J Clin Endocrinol Metab 102:350-353 
17. Hartley J (2017) The jaundiced baby. In: Kelly D (ed) Diseases of the liver and biliary system in children, 4th ed. Wiley, pp 99-126

18. Kamath BM, Piccoli DA, Magee JC, Sokol RJ, Childhood Liver Disease Research and Education Network (2012) Pancreatic insufficiency is not a prevalent problem in Alagille syndrome. J Pediatr Gastroenterol Nutr 55:612-614

19. Kamath BM, Spinner NB, David PA (2014) Cholestatic liver disease. Alagille syndrome. In: Suchy FJ, Sokol RJ, Balistreri WF (eds) Liver disease in children, 4th ed. Cambridge University Press, Cambridge, pp 216-233

20. Krantz ID, Piccoli DA, Spinner NB (1997) Alagille syndrome. J Med Genet 34:152-157. https://doi.org/10.1136/jmg.34.2.152

21. Krantz ID, Colliton RP, Genin A, Rand EB, Li L, Piccoli DA, Spinner NB (1998) Spectrum and frequency of jagged 1 (JAG 1) mutations in Alagille syndrome patients and their families. Am J Hum Genet 62:1361-1369

22. Li L, Krantz ID, Deng Y, Genin A, Banta AB, Collins CC, Qi M, Trask BJ, Kuo WL, Cochran J, Costa T, Pierpont ME, Rand EB, Piccoli DA, Hood L, Spinner NB (1997) Alagille syndrome is caused by mutations in human Jagged1, which encodes a ligand for Notch1. Nat Genet 16:243-251

23. Lin HC, Le Hoang P, Hutchinson A et al (2012) Alagille syndrome in a Vietnamese cohort: mutation analysis and assessment of facial features. Am J Med Genet A 158A(5):1005-1013

24. McDaniell R, Warthen DM, Sanchez-Lara PA, Pai A, Krantz ID, Piccoli DA, Spinner NB (2006) NOTCH2 mutations cause Alagille syndrome, a heterogeneous disorder of the notch signaling pathway. Am J Hum Genet 79:169-173

25. Micaglio E, Andronache AA, Carrera P, Monasky MM, Locati ET, Pirola B, Presi S, Carminati M, Ferrari M, Giamberti A, Pappone C (2019) Novel JAG1 deletion variant in patient with atypical Alagille syndrome. Int J Mol Sci 20:6247

26. Miller SA, Dykes DD, Polesky HF (1988) A simple salting out procedure for extracting DNA from human nucleated cells. Nucl Acids Res 16:1215

27. Mitchell E, Gilbert M, Loomes KM (2018) Alagille syndrome. Clin Liver Dis 22:625-641

28. Penton AL, Leonard LD, Spinner NB (2012) Notch signaling in human development and disease. Semin Cell Dev Biol 23(4):450-457

29. Scheimann A (2020, May 13) Alagille Syndrome. Medscape. http://emedi cine.medscape.com/article/926678-overview.

30. Singh PS, Pati K (2018) Alagille Syndrome and the Liver: Current Insights. Eur J Hepato-gastroenterol 8(2):140-147

31. Turnpenny PD, Ellard S (2012) Alagille syndrome: pathogenesis, diagnosis and management. Eur J Hum Genet EJHG 20(3):251-257

32. Vajro P, Ferrante L, Paolella G (2012) Alagille syndrome: an overview. Clin Res Hepatol Gastroenterol 36(3):275-277

33. Warthen DM, Moore EC, Kamath BM, Morrissette JJ, Sanchez-Lara PA, Piccoli DA, Krantz ID, Spinner NB (2006) Jagged1 (JAG1) mutations in Alagille syndrome: increasing the mutation detection rate. Hum Mutat 27(5):436-443

34. Yuan ZR, Okaniwa M, Nagata I, Tazawa Y, Ito M, Kawarazaki H, Inomata Y, Okano S, Yoshida T, Kobayashi N, Kohsaka T (2001) The DSL domain in mutant JAG1 ligand is essential for the severity of the liver defect in Alagille syndrome. Clin Genet 59(5):330-337

\section{Publisher's Note}

Springer Nature remains neutral with regard to jurisdictional claims in published maps and institutional affiliations.

\section{Submit your manuscript to a SpringerOpen ${ }^{\circ}$ journal and benefit from:}

- Convenient online submission

- Rigorous peer review

- Open access: articles freely available online

- High visibility within the field

- Retaining the copyright to your article

Submit your next manuscript at $\boldsymbol{\nabla}$ springeropen.com 